\title{
Associate Teacher Perspectives of the Triumvirate Relationship in Teacher Education: The Role of Faculty Advisors
}

\author{
Karen Roland \\ University of Windsor
}

\begin{abstract}
The literature suggests that teacher candidates identify the field experience as a valued aspect of their pre-service education. In field experience, associate teachers are significant contributors to the success of the triumvirate relationship (associate teacher/teacher candidate/faculty advisor). A study was conducted using an anonymous questionnaire to explore, from the perspective of associate teachers, potential strategies and/or recommendations that may strengthen this relationship. The findings of the study, specifically related to the expectations concerning the role of the faculty advisor to support associate teachers, are presented. Reflective practice is discussed in terms of its relevance to the triumvirate relationship. The article concludes with a discussion of the implications of the findings in terms of strengthening the triumvirate relationship in teacher education.
\end{abstract}

Key words: pre-service teacher education; triumvirate; experiential learning; reflective practice; community of practice.

Karen Roland is the Experiential Learning Specialist for the University of Windsor, Faculty of Education. In this role Karen consults and collaborates with teacher candidates, faculty and school partners as an impartial resource, and assists in the development of strategies and programming to address equity and social justice issues in teacher education. Karen holds a PhD in Educational Studies. Areas of research interest include: social justice education, educational equity, teacher education, diversity and policy and administration.

Karen Roland, PhD, Experiential Learning Specialist, Faculty of Education, Room 3332, University of Windsor, 401 Sunset Avenue, Windsor, ON N9B 3P4. E-mail: roland1@uwindsor.ca

Brock University, Volume 19, No. 2, Spring 2010, 36-47. 


\section{Introduction}

The field experience component of teacher education provides teacher candidates with the opportunity to link the pedagogical theory gained through faculty course instruction, with practical experiences in the classroom, thereby transforming knowledge into understanding as a core aspect of experiential learning in teacher education. Teacher candidates apply pedagogical theory gained in university curriculum as knowledge in practice in the classroom - as their praxis. Roberts (2003), in discussing Dewey's Experiential Learning Theory suggests that "knowledge is what students learn from their experiences" (p. 5), and of particular significance to pre-service teacher education, is that this knowledge may be then applied in later (future) 'real life' situations. This 'real life' application of knowledge gained through experience in the classroom is of critical importance to teacher candidate efficacy in developing their teaching practice, and what is purported by Osterman (1990), is also necessary for the development of reflective practice. Osterman indicates that reflective practice may be instrumental in encouraging 'constructed' ways of knowing created through a process that integrates reflection with constructed knowledge, this process developed by way of systematic observation and deliberate analysis on the part of the learner.

Webb (2003), in defining learning asserts that there are two principal definitions of learning in terms of outcomes - specific results (objects or states of being), and that of an "activity or change" (p. 7) within the learner. Furthermore, Webb opines that Dewey's (1938) definition of learning suggests that knowledge, or the application of said knowledge, is acquired through personal experience and derived within a social context to create meaning and behavioural outcomes. This definition melds well with the concept of 'praxis' in the experiential component of teacher education often referred to as the field experience. Further, this definition suggests that the application of skills and abilities, or practical experience linked with theoretical knowledge, creates meaning in terms of professional practice for teacher candidates in teacher education programs.

Webb (2003) shares a perspective of experiential learning theory as experience-based learning involving "four sequential operations performed on experience" (p. 22). She asserts that there are four modes of operation performed on experience representing differing structures and behaviours, including affective (concrete experiencing), perceptual (reflective observation), symbolic (abstract conceptualization), and behavioural (active experimentation). Webb refers to experience as meaning transformed through processes mediated by personal perception, or as the reflective process of a learner generating meaning through introspection and reflective practice. Furthermore, she purports that a dialectic tension exists between each "oppositional pair of modes" (p. 22), suggesting that structures and behaviours move to greater levels of complexity as a result of the "creative tensions" emanating from the "choices the individual makes in their assimilation and accommodation of experience" (p. 22). These modes or operations are germane to the field experience component of teacher education, particularly, the aspect of 'reflective observation'.

Osterman (1990) points out that teacher education programs have incorporated the concepts of reflective practice in an effort to effectively develop professional skills in teacher candidates. She provides a definition of reflection as the "mindful consideration of one's actions, specifically, one's professional actions" (p. 134), in a dialectic process that links thought with action to enhance professional practice. This perspective of professional growth developed through experience which is mediated through reflection to influence behaviour, closely mirrors 
the process of 'reflective observation' that Webb (2003) notes as a mode of experiential learning theory. Furthermore, Osterman states that:

Reflective practice redefines both the concept of learning, and the role of the learner in the learning process. By emphasizing the importance of both personal experience and ideas, reflective practice establishes the importance of theory, but counsels against the study of theory in isolation from practice. Recognizing that the search for knowledge begins with experience and that no learning takes place unless the learner is both involved in and transformed by the learning process, reflective practice also emphasizes that the practitioner is central to the learning process (p. 142).

Schön (1989) contends that learning in a professional context such as teaching requires that the learner or practitioner reflect on their knowing, or what he refers to as "reflect-in-action" (p. 6). And furthermore, Schön opines that reflective practicums, as an integrative approach to learning in a profession, would allow the learner the time to "unlearn initial expectations, to master the practice, and to shift repeatedly back and forth between reflection on and in action" (p. 9), or in other words, to become "proficient at a kind of reflection-in-action" (p. 8). This reflection of knowing in-practice has significance in terms of 'praxis' in teacher education which is the application of knowledge, skills, and abilities developed within a meaningful context or learning environment (the classroom), and facilitated through the mentorship and coaching provided by associate teachers. The associate teacher role may be defined as Clarke (2001) suggests, as a professional role that encompasses teacher education as part of its daily responsibility. Within the professional learning context of the field experience component of teacher education, the associate teacher plays a pivotal role as a member of a triumvirate relationship.

The triumvirate relationship in teacher education may be described as a learning partnership amongst three members: the associate teacher, the teacher candidate, and the faculty advisor. The success of this professional relationship may rest significantly on the facility of the associate teacher to coach, mentor, facilitate and supervise teacher candidates in their development as teaching professionals (Ferrier-Kerr, 2009). However, it is also important to note Clarke's (2001) assertion that there has been a significant shift in the academy in recent years towards the recognition of the importance of the "roles of teacher educator and scholar" as "one and the same" (p. 610) in the burgeoning field of study - teacher education. In light of this, it is important to consider Osterman's (1990) contention that universities play an important function in fostering reflective practice in teacher education, and which may be argued, is an essential component in the development of a community of practice in teacher education.

Wenger and Snyder (2000) state that the purpose of a community of practice is to “...develop members' capabilities; to build and exchange knowledge" (p. 142), and that furthermore, the dynamic nature of a community of practice involves a reciprocal approach to learning on the part of all the participants. Goodnough, Osmond, Dibbon, Glassman and Stevens (2009) assert that approaches to teacher education that integrate theory and practice through the pre-service experience, also assist in the development of the knowledge and skills necessary in a professional community of educators. Therefore, a community of practice in teacher education may involve aspects of co-learning in a teaching community which affords the members of the triumvirate (associate teacher, teacher candidate, faculty) with what Wenger and Snyder identify as an opportunity to actively share experiences and knowledge in creative ways. They indicate 
that, "communities of practice generate knowledge, they renew themselves" (p. 143), which is congruent with Schön's (1989) perspective of reflective practice as involving practitioners "knowing-in-practice" (p. 6), or reflecting on practice in the midst of doing. Therefore, as Johnson (2006) contends, learning in a community of practice is not the straightforward acquisition of skills and abilities, but rather a process of "progressive movement from external, socially mediated activity to internal meditational control by individual learners, which results in the transformation of both the self and the activity" (p. 238).

Although much research has been conducted regarding the practicum or field experience component of teacher education (Beck \& Kosnik, 2000, 2002; Duquette, 1996; Faire, 1994; Ferrier-Kerr, 2009; Goodnough, et al., 2009; Joong, 2007; Macdonald, Baker \& Stewart, 1995; Neil, 1993; Roth, Masciotra, Boyd, 1999), a study was conducted using an anonymous online questionnaire to investigate, from the perspective of associate teachers, how they would define their role, what supports the faculty could provide to them to meet the expectations of their role, and the benefits and disadvantages for associate teachers of having a teacher candidate in their classroom. This article will present the findings of this study relevant to what associate teachers' perceptions are of the supports university faculty may provide the associate teacher in meeting the expectations of the associate/mentor role.

\section{The Study}

\section{Participants}

The sample population for the study was comprised of 947 associate teachers employed with three school boards; these school boards routinely participate in the field experience component of the faculty of education pre-service teacher education program by hosting teacher candidates in their schools. There were 134 respondents to the online anonymous survey questionnaire - approximately $14.2 \%$ of the sample. The sex of participants was identified by $67.2 \%$ of the respondents as $31.1 \%$ male and $68.9 \%$ female. The mean number of years of teaching experience was reported as 12.7 years by $67.2 \%$ of the respondents. Participation in the field experience component of the teacher education program was reported by $67.9 \%$ of the respondents as $60.4 \%$ (0-5 years of experience), $27.5 \%$ (6-10 years experience), and $12.1 \%$ (11 or more years of experience). Research ethics clearance was obtained from the university, as well as all participating school boards to conduct research using an anonymous online survey during the spring of 2008.

\section{Method}

An anonymous online survey, the Associate Teacher Feedback: Anonymous \& Confidential Questionnaire, was developed to investigate associate teacher perceptions concerning their role as an associate teacher; the support that the faculty advisor may be able to provide the associate teacher, and finally, recommendations from associate teachers concerning strategies to strengthen the triumvirate relationship between teacher candidate/associate teacher/faculty advisor, from the perspective of associate teachers. The survey questions were developed and adapted from the studies conducted by Beck \& Kosnik (2000, 2002), Duquette (1996), Faire (1994), Joong (2007), Macdonald et al. (1995), and Neil (1993). 


\section{Questionnaire}

The questionnaire was constructed in three sections to obtain associate teachers' perspectives concerning: 1) the expectations of the role of an associate teacher; 2) the role of the faculty advisor to support the associate teacher in their role; and 3) the benefits/disadvantages for associate teachers of having a teacher candidate in their classroom. The survey instrument utilized a variety of questioning styles to encourage response from associate teachers including, open-ended questions that invited associate teachers to share their thoughts and insights regarding their role, questions that asked associate teachers to rank order variables in terms of importance and/or support, and questions that asked associate teachers to respond to 5-point Likert scale questions indicating the extent to which they agreed or disagreed with a set of statements. Associate teachers were given the choice of completing the whole questionnaire at one time or answering the questionnaire by sections and returning at a later time/date to complete the entire questionnaire. All associate teacher responses to this questionnaire were anonymous.

The next section of this article will present the findings of the study, specifically the second section of the survey in which the participants, associate teachers, reported how they perceived faculty advisors could support them in meeting the expectations of their role in the field experience component of the teacher education program.

\section{Findings}

The second section of the anonymous questionnaire was designed to inquire, from the perspective of associate teachers, what their expectations were concerning the role of the faculty advisor. The first question in this section was open-ended and asked associate teachers to elaborate on what their expectations were concerning the role of the university faculty advisor. The response from associate teachers to this question was categorized as three kinds of support: 1) that of the advisor as a counsel for the teacher candidate and/or the associate teacher, 2) the advisor as a liaison or intermediary in the triumvirate relationship, and 3) the advisor as an assessor of teacher candidate progress and growth as a future member of the teaching profession. In describing these categories of faculty advisor support I cited the associate teachers' responses to provide a nuanced understanding, and to clarify the reasons behind their points of view.

The category of support identifying the faculty advisor as counsel for both associate teacher and teacher candidate is illustrated in the following statements shared by associate teachers concerning their expectations of the faculty advisor:

To support teacher candidate and associate teacher; to advise and counsel.

An advisor should be in consultation with the associate on strengths, weaknesses and next steps (more than once during a placement).

[To be] an anchor for the student teacher.

A person who guides and mentors the teacher candidate. Similar to associate teacher.

To work with teacher candidates that are having difficulty and provide more one-on-one time to get them ready for their practicum. 
To observe a student teacher on behalf of the university, to be another set of eyes on the student teacher's progress besides the associate, to offer advice to both the associate and student, to give the university's perspective on the classroom.

The next category of support characterized the faculty advisor as a liaison or intermediary and is indicated in the following statements that were shared by associate teachers:

To oversee the evolution of the teacher candidate and to act as an intermediary should any difficulties in the associate/student teacher relationship arise.

The role of the advisor is to make sure everything is running smoothly between the associate and the teacher candidate.

To have regular contact with both candidate and associate, and support both.

The faculty advisor should have greater contact with the associate to address any issues immediately. They help identify if the candidate 'fits' into the teaching situation.

To guide and advise the candidate, but also to speak to me regarding what the advisor would like me to do to help the candidate. What areas need reinforcing? He or she may see something that I have missed.

To support and encourage the student teacher, giving feedback and pointers when needed. To listen to an associate teacher's feedback and concerns, and when needed, to help the student teacher and associate to mediate and to set goals to improve the student teacher's teaching prowess.

They need to be the middle 'person.' They need to know what the faculty expects and the associate teacher expects, and if for some reason the candidate isn't getting that picture, the advisor needs to make it clear to them. I feel that the advisor needs to be close at hand to each associate teacher.

Associate teachers also identified a category of support characterizing the advisor as an 'assessor' evaluating the teacher candidate's progress. The following statements were shared by associate teachers which illustrate this category of support:

The faculty advisor should observe the candidate teach a lesson and converse with the associate on the progress of the candidate. They should assess the candidate's knowledge of the curriculum they are to teach.

...meet with candidates a reasonable number of times to discuss placements, give ideas and support, observe them in their placements, and discuss their progress with associates. 
My expectations are that the faculty advisor is there to advise and evaluate the candidate based on the candidate's performance with respect to what they have been taught at the faculty.

To be accessible should there be problems in the candidate's placement. To observe the candidates in their teaching roles and provide relevant feedback. To assist those candidates who are struggling with certain aspects of their placement. To provide feedback to the associate and their expectations of candidates should there be a huge difference of opinion.

They [faculty advisors,] see their candidates in different settings and have a better idea if the candidate is weak or strong all the time or just in one specific setting. On the other hand, the advisor only sees the candidate one period of possibly a one month placement and should therefore find out what the classroom teacher has to say about a candidate. Sometimes a candidate may have a bad lesson or an exceptionally good lesson, and the advisor and associate should have time to share their opinions to come to a more accurate assessment of the individual candidate.

To assess the teacher candidate's progress at specific points throughout the year.

I would suggest that these approaches to faculty advisor support for the associate teacher as counsel, liaison, and assessor, are indicative of supporting a mentoring/coaching model of consultation and collaboration in teacher education. It is important when reviewing the findings of this study concerning associate teacher expectations of the faculty advisor, to consider that associate teachers in this study indentified two conceptualizations of the associate teacher role as either that of a mentor, characterized as an associate who models, coaches and nurtures the success of teacher candidates in a reciprocal learning process, or that of an associate teacher as an experiential learning specialist who provides the teacher candidate, as an apprentice, with the opportunity to experience the 'realities' of the classroom by providing the candidate with the necessary pedagogical techniques and skills. These conceptualizations are somewhat similar to the broad conceptions Beck and Kosnik (2000) discuss as the "critical interventionist model" (p. 208) described as a reciprocal learning and team teaching approach which incorporates associate feedback and intervention for teacher candidate improvement; and the "practical initiation model" (p. 208) which suggests a practical initiation or apprenticeship model of teacher education. The orientation of associate teachers toward either a mentor/coaching model versus an apprenticeship model in the field experience component is significant, because as Goodfellow and Sumsion (2000) suggest, field experience involves learning "how to be a teacher rather than simply learning to do the work of a teacher" (p. 247).

Associate teachers, in addition to elaborating on their expectations concerning categories of support, were also asked to rank the support that advisors could provide to them during the field experience component. Specifically, as listed below, associate teachers were asked to rank the following factors in terms of how supportive they were to associate teachers:

- faculty advisors collaborating with associate teachers to clarify the goals of the pre-service program; 
- the availability of the faculty advisor for consultation, particularly when a teacher candidate has been identified as 'at risk';

- providing opportunities for associate teachers to become involved with initiatives that support school development;

- the faculty advisor providing timely correspondence along with contact information and a suggested schedule for classroom visits;

- frequent classroom visits by the faculty advisor;

- the faculty advisor stressing the importance of professional conduct on the part of the teacher candidate;

- providing opportunities for associate teacher involvement in the Bachelor of Education admission process; and

- 'other' factor(s) as identified by the associate teacher participant.

The findings of the study indicate the following as the two factors ranked as most supportive by associate teachers: the first factor was identified as the availability of the faculty advisor for consultation, particularly when teacher candidates are struggling; and the second factor identified as most supportive, was the faculty advisor ensuring that teacher candidates are prepared and knowledgeable concerning the need for professionalism both in the classroom and in the school community. Next, in rank order, associate teachers identified the need for advisors to ensure timely communication with them. This was clearly articulated in this associate teacher's comment, "We need their [faculty advisor's] contact information before students enter! We should not have to track them down. An introductory letter would help with a little bit of information about them." Ranked fourth in terms of the level of support for associate teachers, was the need for frequent classroom visits on the part of faculty advisors. The ability of associate teachers to collaborate in the development of goals for the pre-service teacher education program was ranked next. The associate teacher participants ranked the following as the least supportive factors that advisors could provide them: associate teacher involvement in the admission process, and associate teacher involvement with initiatives that support school development.

In this study, associate teachers clearly articulated their expectations surrounding a need for stronger ties with faculty, for opportunities to consult and collaborate, particularly with faculty advisors. Roth and Boyd (1999) refer to 'coparticipation in practice' as a method that fosters competency in a teaching-learning environment and suggest that what makes practitioners competent in this context, is that the knowledge gained is done so through coparticipation with competent others, in a community of practice. The research conducted by Roth et al. (1999) underscores the importance of relationship building between university and school partners, emphasizing learning through co-teaching to build relationships based on mutual understanding and making the linkages between theory and practice as praxis in teacher education. Similarly, the findings of research conducted by Larson and Goebel (2008) stresses that co-learning opportunities developed through a partnership between the school and the university may facilitate the theory-to-practice connection for teacher candidates. Roth and Boyd claim that teaching, tied with the 'in the classroom' experience, makes possible the development of active knowlegeability, what they claim is, "... a form of embodied knowing acquired in praxis" (p. 65). The findings clearly articulate the need for consultation and collaboration amongst the members of the triumvirate, associate teacher/teacher candidate/faculty advisor. Of particular importance in strengthening this relationship was the need identified for closer ties between the associate teacher and the faculty advisor. 


\section{Discussion and Implications}

The study findings indicated that associate teacher participants characterized the support of faculty advisors as that of counsellor for themselves as well as teacher candidates, liaison or intermediary in the triumvirate partnership, and that of an assessor of teacher candidates' professional growth. Furthermore, the findings underscored this fact by confirming that associate teachers would welcome closer connections with faculty advisors in terms of more frequent visits to their classrooms, and greater opportunities to conference with advisors concerning teacher candidate progress as future members of the profession. Beck and Kosnik (2000) assert that there is a need to not only clarify the role and expectations of associate teachers (as investigated in the current study), but also a need to ensure that teacher education programs are working in concert with associate teachers in the field. By strengthening ties with associate teachers as partners in the teacher education process, connections between theory and practice may be better clarified for teacher candidates.

The connection and integration of theory and practice in teacher education may be facilitated by sharing ideas and insights through the development of a community of practice with members of the triumvirate relationship. This community of practice would support, value, and integrate the theoretical knowledge obtained by teacher candidates through university instruction, with the working knowledge (pedagogy) they gain in field experience (Viskovic, 2006). However, He (2009) cautions that while a community of practice in teacher education programs may create environmental conditions conducive to learning, the "mere presence in social activities does not guarantee learning to happen. Individuals have to elect to participate and construct their understandings through participation" (p. 154). Therefore, it may be argued that a professional community of practice in teacher education must involve the active engagement of all members of the triumvirate relationship in reflective practice.

Osterman (1990) refers to reflective practice as a process which promotes professional growth through change, involving not only reflective practice, but also agency as in the ability to take action and create change. She states that, "through reflection, professionals develop ideas about how to do things more effectively, and they transform these ideas into action" (p. 145). This reflective aspect of professional learning has implications for all the members of the triumvirate relationship in terms of the promotion of organizational leadership and educational reform brought about through processes that foster critical thinking and analysis. Osterman contends that reflective practice must emphasize the importance of theory and ideas, as well as experience and reflection:

....reflective practice challenges educators to become personally and actively involved in the creation of better schools. It challenges them to examine the ideas which shape schools and to actively engage in reconstructing that reality. Without restructuring the underlying mindscapes, restructuring of schools will not occur. (p. 151)

And yet, in her statement she counters that within the school structure, to facilitate educational reform, there needs to be greater support and valuing of the professional development of associate teachers:

We espouse the view that one becomes a skilled practitioner through an ongoing process of experience, reflection, and experimentation, but our actions contradict our 
words....There is little open discussion of problems, and only a few instances of collaborative problem-solving efforts....Instead of recognizing that so many of the important problems confronted by schools are shaped by social reality, we continue to view problems as individual deficiencies. (Osterman, 1990, p. 147)

Given this, and as Osterman (1990) asserts, universities may play a key role in fostering reflective professional practice; reflective practice to create an environment that invites consultation and collaboration with which to critically examine the social reality of the classroom and then to transform ideas into actions. Consultation and collaborative initiatives between the university and their school partners may take the form of action research, professional development for associate teachers hosted by the faculty, in-service courses specifically related to defining the expectations of the associate teacher role, and online learning communities that provide information such as faculty pre-service curriculum as well as opportunities for discussion amongst associate teachers and faculty to jointly share ideas and insights.

Therefore within a community of practice, the triumvirate relationship in the field experience component of teacher education may provide an opportunity to encourage reflective practice, and to promote active consultation and collaboration between the associate teacher and the faculty advisor as a representative of the university, and between the associate teacher and the teacher candidate as the future generation of the teaching profession. As Viskovic (2006) asserts in discussing the concept of community of practice, "participation in a community has implications for understanding and supporting learning" (p. 326), and that, "for communities, learning is an issue of refining their practice and ensuring new generations of members" (p. 326). These perspectives are congruent with the findings of this study in which an associate teacher stated that one of the expectations of the faculty advisor is, "to ensure our educational system is getting the best possible future teachers." These perspectives highlight the need for adopting reflective practice and reciprocal approaches to learning in the field experience component of teacher education.

In conclusion, I would suggest that faculty advisors have a pivotal role to play in strengthening the triumvirate relationship through the encouragement of reflective practice amongst the members of this learning partnership. This relationship may yield benefits not only for the future of the teaching profession, but also for the educational system through the creation of a learning environment which actively and critically examines what constitutes effective and professional teaching practice. 


\section{References}

Beck, C. \& Kosnik, C. (2000). Associate teachers in pre-service education: Clarifying and enhancing their role. Journal of Education for Teaching, 26(3), 207-224.

Beck, C. \& Kosnik, C. (2002, Spring). Components of a good practicum placement: Student teacher perceptions. Teacher Education Quarterly, 29(2), 81-98.

Clarke, A. (2001). The recent landscape of teacher education: Critical points and possible conjectures. Teaching and Teacher Education, 17(5), 599-611.

Dewey, J. (1938). Experience and education. New York: Macmillan.

Duquette, C. (1996, Winter). Partnerships in preservice education: Perceptions of associate teachers and student teachers. McGill Journal of Education, 31(1), 69-81.

Faire, M. (July 1994). Improving the practicum: the professional development needs of lecturers, associate teachers and student teachers. Paper presented at the Annual Conference of the Australian Teacher Education Association (24 ${ }^{\text {th }}$, Brisbane, Queensland, Australia, July 3$6,1994)$.

Ferrier-Kerr, J. L. (2009). Establishing professional relationships in practicum settings. Teaching and Teacher Education, 25(6), 790-797.

Goodfellow, J. \& Sumsion, J. (2000). Transformative pathways: Field-based teacher educators' perceptions. Journal of Education for Teaching, 26(3), 245-255.

Goodnough, K., Osmond, P., Dibbon, D., Glassman, M. \& Stevens, K. (2009, February). Exploring a triad model of student teaching: Pre-service teacher and cooperating teacher perceptions. Teaching and Teacher Education, 25(2), 285-296.

He, A. E. (2009, March). Bridging the gap between teacher educator and teacher in a community of practice: A case of brokering. System: An International Journal of Educational Technology and Applied Linguistics, 37(1), 153-163. doi: 10.1016/j.system.2008.06.006

Johnson, K. E. (2006, March). The sociocultural turn and its challenges for second language teacher education. TESOL Quarterly 4O(1), 235-257.

Joong, P. (May 27, 2007). Teacher education practicum in Ontario. Presentation at CSSE. Saskatoon, SK.

Larson, W. C. \& Goebel, A. J. (2008, May). Putting theory into practice: a professional development school/university co-teaching project. Journal of the Scholarship of Teaching and Learning, 8(2), 52-61.

Macdonald, C.J., Baker, D., \& Stewart, S.R. (1995, Winter). Student teachers in the classroom: Associate teachers' perspectives. McGill Journal of Education, 30(1), 73-95. 
Neil, R. (1993, Fall) Practicum associates' views on their role and the program of pre-service education. Education Canada, (33)3, p. 8. Retrieved from http://proquest.umi.com/pqdlink?vinst=PROD\&fmt=3\&startpage $=-$ $1 \&$ ver=1\&clientid=2241\&vname=PQD\&RQT=309\&did=705555591\&exp=04-06$2014 \&$ scaling $=$ FULL $\&$ ts $=1239132901 \& v$ type $=P Q D \&$ rqt $=309 \& T S=1239132944 \&$ client $\mathrm{Id}=2241$

Osterman, K.F. (1990, February 2). Reflective practice: A new agenda for education. Education and Urban Society, 22(2), 133-152.

Roberts, T.G. (2003, August). An interpretation of Dewey's experiential learning theory. U.S. Department of Education, Office of Educational Research and Improvement, Educational Resources Information Center, Report: ED481922. 11pp. Retrieved from http://www.eric.ed.gov/ERICDocs/data/ericdocs2sq1/content_storage_01/0000019b/80/1 b/82/92.pdf

Roth, W. M. \& Boyd, N. (1999). Coteaching, as colearning, is praxis. Research in Science Education, 29(1), 51-67.

Roth, W. M., Masciotra, D. \& Boyd, N. (1999). Becoming-in-the-classroom: a case study of teacher development through coteaching. Teaching and Teacher Education, 15, 771-784.

Schön, D. A. (1989, Fall). A symposium on Schön's concept of reflective practice: Critiques, commentaries, illustrations. Journal of Curriculum and Supervision, 5(1), 6-9.

Viskovic, A. (2006, November). Becoming a tertiary teacher: Learning in communities of practice. Higher Education Research \& Development, 25(4), 323-339.

Webb, M. W. (1980). A definitive critique of experiential learning theory. (Unpublished doctoral dissertation, Case Western Reserve University, Cleveland, Ohio).

Wenger, E. C. \& Snyder, W. M. (2000, January/February). Communities of practice: The organizational frontier. Harvard Business Review, 78(1), 139-145. 